\title{
SHARIA HOTEL ATTRIBUTES AND THEIR URGENCY FOR MUSLIM TOURISTS' NEEDS IN MAQASID SHARIAH PERSPECTIVE
}

\author{
Rakhman Priyatmoko ${ }^{1}$ Addin Maulana $^{2}$ Dini Oktaviyanti ${ }^{3}$ \\ ${ }^{123}$ Direktorat Kajian Strategis-Kemenparekraf/Baparekraf \\ J1. Medan Merdeka Barat No. 17 Jakarta \\ moko.budpar@gmail.com
}

\begin{abstract}
The expansion of Sharia hotels is increasingly attracting industry players and scholars in the tourism sector. Although some researchers have focused on studying Sharia hotels' attributes, research examining these attributes deeply based on the Maslahah level in the Maqasid Shariah has not been found. By employing the literature review, this study aims to gather Sharia hotels' attributes and analyze their urgency from the Maslahah perspective using a descriptive method. The results showed that halal food availability, the prohibition of alcoholic victuals, and gender separation in fitness facilities are classified in the Dharuriyat category (fundamental). Besides, the availability of the Quran, praying amenities, and the Qibla sign are grouped in Hajiyat (secondary). Lastly, Tahsiniyat (tertiary) attributes include Ramadan special services, a particular lobby floor for women, and Muslim staff domination. Sharia hotels' other attributes can be extended for further research as long as they conform to Sharia law principles.
\end{abstract}

Keywords: Attributes, Sharia hotels, Maslahah, Maqasid Shariah

\section{Introduction}

Sharia-concept hotels, also known as halal hotels, Islamic hotels, or Muslimfriendly hotels, are continuously attracting researchers and business players in the hospitality industry nationwide and overseas. The surprising response by hotel industry players is shown by the increasing Sharia hotel number in countries where Muslims are not the majority, such as the Philippines, Thailand, and Russia (Battour, 2018). The mushroomed hotels with Islamic attributes in those countries confirm that destination managers and tourism industry players are aware of Muslim tourists' potential market.

The concept of a Sharia hotel is a combination of "hotel" and "Sharia" terminology. A hotel is defined as accommodation consisting of rooms in a building complex equipped with food and drink services, entertainment, and several other facilities. Generally, hotel quality is characterized by star and no-star labels (Statistics Indonesia, 2018, p. 376). On the other hand, Sharia is Islamic law derived

Received: 2020-07-30 | Reviced: 2020-12-03 | Accepted: 2020-12-31

Indexed : DOAJ, Garuda, Crossref, Google Scholar, Sinta | DOI: https://doi.org/10.29313/amwaluna.v5i1.6464 
from the Quran and Sunnah, aiming to control all trade and industrial activities, including tourism (Battour et al., 2010).

As a combination of the two terms mentioned earlier, a Sharia hotel provides services following Sharia principles (Kamri et al., 2018; Saad et al., 2014) by targeting market portions where most guests are Muslims (Saad et al., 2014). This typical hotel adheres to a Sharia system in its operations: financial system, ethical standard, entertainment styles, spatial configuration, and Zakat (Islamic tithe). Furthermore, their organizational design is also adjusted to Sharia principles without neglecting the society norms and respecting all Muslim and non-Muslim citizens (Janitra, 2017, p. 18).

Religious features play an essential role in influencing Muslim customer decisions towards the hotel and tourism sector (Azhani et al., 2017). These features can be interpreted as Islamic representations implemented in a hotel. Muslim tourists will always favor hotels with Islamic attributes, especially for the sake of halal food and praying facilities.

The practice of Sharia hotel business has now become a worldwide trend as it has an up-and-coming market (Mansyurah, 2018). The growth of Sharia hotels is influenced by two factors: (1) increasing awareness of Muslim tourists towards the principal needs of Sharia custom; (2) the swift growth of the global Muslim tourist market (Salleh et al., 2014). As of 2018, about 140 million international Muslims were mobilizing worldwide, and this number is projected to increase up to 230 million by 2026 (Mastercard \& CrescentRating, 2019).

No official data is covering the number of Sharia hotels globally until now. Although official data regarding the number of self-proclaimed Sharia hotels in Indonesia is unavailable, three Sharia hotels have received Sharia hotels certificates issued by the National Sharia CouncilIndonesian Ulema Council (DSN-MUI) (DSN-MUI, 2020). In comparison, Malaysia, which was on the top-rank together with Indonesia in the 2019 Global Muslim Travel Index, has 42 hotels with the status of "Muslim-friendly" under the Muslim-Friendly Accommodation Recognition (MFAR) scheme (Yusof, 2020).

In the academic discipline, the theme of Sharia hotels has positive impressions. Based on a quest done via https://www.sciencedirect.com, as many as 28 published journals were found containing the keyword "Sharia-compliant hotel" with a study range of 2007-2020. Meanwhile, in the Digital Reference Guard (GARUDA) through http://garuda.ristekbrin.go.id/, 58 
journals were found with the keyword "Sharia hotels" filtered from 2012-2020. Moreover, in the 2015-2020 publication range within the same source, ten and seven articles with each keyword "Halal hotel" and "Islamic hotels" were found.

When Malaysia already has "Muslim Friendly Hospitality Services Requirements" (Idris \& Wahab, 2015), the presence of Sharia hotels, unfortunately, has not received substantial attention from the Indonesian government. In terms of regulations, there are no laws issued by Indonesia's Ministry of Tourism related to Halal tourism development by the time this research was conducted.

A Fatwa (legal opinion from Islamic view) containing guidelines for implementing national tourism based on Sharia principles was once issued by the DSN-MUI Number 108/DSN-MUI/X/2016 (DSN-MUI, 2016). However, the contents of the Fatwa are broad and not a product of government policy. Therefore, a more technical explanation is needed. Indonesia once enjoyed a Regulation of the Minister of Tourism and Creative Economy Number 2 of 2014 concerning the Guidelines for Implementing Sharia Hotel Businesses (Rachmiatie et al., 2020). However, it was not until the 2016 revocation resulting in a governing vacuum for Sharia hotels.
The absence of constitutional laws causes the managers of Sharia hotels in Indonesia to implement Sharia hotels criteria based on their interpretations that may differ from one to another. Different interpretations have the potential in different service executions, although the concepts offered are similar. Regulations for Sharia hotels containing formal standards related to Halal tourism, including Sharia hotels, should exist as a guideline for hotel industry players to establish and operate this typical concept. Therefore, a systematic effort to observe and investigate the basic concepts of Sharia hotels is needed.

This study attempts to answer Sharia hotels' attributes and examine their urgency seen from the Muslim tourists' needs based on the above background. The results are expected as input for the central and local governments in formulating regulations and standardization related to Sharia hotels. Furthermore, hotel industry players are expected to gain insight into understanding the concept of Sharia hotels comprehensively.

\section{Literature Review}

The studies on Sharia hotel attributes often attract the attention of researchers in the tourism sector. Rosenberg \& Choufany (2009) divided Sharia hotels' attributes into three aspects: functionality, interior design, 
and financial. Saad et al. (2014) used the Delphi approach by weighting each category formulated previously by Rosenberg \& Choufany (2009).

Battour (2018) classified Sharia hotels' attributes into two parts: Muslimfriendly hotel rooms and Muslim-friendly service, while Kamri et al. (2018) divided Sharia hotels' attributes into four aspects: food and beverage, front office, staff, and communal facilities. Several discussions on Sharia hotel attributes without grouping their characteristics were also conducted by previous researchers (Alam et al., 2019; ElGohary, 2016; Henderson, 2010).

Karim et al. (2017) found two attributes that distinguish Islamic hotels and Sharia hotels: the use of Islamic clothing and swimming pool management. If staff in Islamic hotels were just encouraged to dress in Islamic clothing, it was compulsory in Sharia hotels. Swimming pools in Islamic hotels have separate areas for men and women, but there is only one swimming pool with strict time management for Sharia hotels.

In other research, Kamri et al. (2018) and Janitra (2017) discussed the connection between the attributes of Sharia hotels and the Maslahah (the concept of basic goodness) in Maqasid Shariah (objectives in Sharia). According to them, these attributes can be grouped using the three-level
Maslahah in Maqasid Shariah, such as the Dharuriyat (primary), Hajiyat (secondary), and Tahsiniyat (tertiary).

After reviewing some former studies, it can be inferred that no research aims explicitly to discuss Sharia hotels' attributes with the Maqasid approach. Although Kamri et al. (2018) and Janitra (2017) have provided frameworks that Sharia hotels' attributes can be categorized using the Maqasid approach, they have not discussed each attribute's urgency deeply.

\section{Methods}

This research employs a qualitative approach and collects data regarding the attributes of Sharia hotels, sourced from six publications by Rosenberg \& Choufany (2009), Henderson (2010), Battour (2018), El-Gohary (2016), Alam et al. (2019), and Kamri et al. (2018). Those publications were selected purposely since they were considered sufficient in accommodating the data needed to satisfy the research questions.

Data analysis was carried out using a descriptive approach to describe and interpret a state or object (Zellatifanny \& Mudjiyanto, 2018). This study summarized the attributes of Sharia hotels from previous studies and categorized them based on the level of Maslahah in the Maqasid Shariah. Subsequently, the categories were interpreted for in-depth discussions. 


\section{Discussion}

\section{The Theory of Maqasid Shariah}

The Sharia hotels' attributes analysis in this study uses the Maqasid al-Sharia (Maqasid Shariah) approach. Abdul-Malik al-Juwaini (d. $478 \mathrm{H}$ ) first included the term "Maqasid al-Sharia" in his book, titled alBurhan fi Ushul al-Fiqh (Busyro, 2019). As one of the earliest contributors to the Maqasid theory, al-Juwaini used the terms al-Maqasid and al-Masalih al-Ammah (public interest) interchangeably (Auda, 2008).

Maqasid Shariah was recognized as an independent scientific discipline during the era of Imam al-Syatibi (d. $790 \mathrm{H}$ ) (Khatib, 2018). Through the book, titled AlMuwafaqat, al-Syatibi was known as "the Father of the Maqasid Shariah" (Busyro, 2019). Al-Syatibi used different terms in referring to Maqasid Shariah, including Maqashid al-syariah, al-Maqasid alsyar'iyyah, and Maqasid min syar'i al-hukm; all three have the same goals granted by Allah SWT to obtain benefits of this world and the hereafter (Abdurrahman, 2020). According to al-Ghazali (d. $505 \mathrm{H}$ ), Maslahah's principal aims to take advantage and reject disadvantage (Janitra, 2017). The advantage appears as the benefit of religion (al-din), soul (al-nafs), mind (al-'aql), family (al-nasb), and the property (al-maal) (Busyro, 2019).
The traditional classification on the need levels is one of the dimensional classifications of Maqasid Shariah (Auda, 2008). Al-Ghazali, in his book titled alMustashfa, divided three levels of needs into (1) Dharuriyat (primary needs), (2) Hajiyat (secondary needs), and (3) Tahsiniyat (tertiary needs) (Auda, 2008; Arfan, 2013). Similar to al-Ghazali, al-Syatibi also divided Maslahah levels according to three series of human needs: Dharuriyat, Hajiyat, and Tahsiniyat (Betawi, 2018; Busyro, 2019; Kara, 2012; Zatadini \& Syamsuri, 2018).

Dharuriyat is any essential criteria that must exist in order to maintain religion and faith. Anything that can make life easier and help get rid of difficulties (in some ways, it supports the attainment of Dharuriyat) is Hajiyat. Meanwhile, Tahsiniyat refers to matters used to supplement or improve the quality of life and human dignity (Janitra, 2017, pp. 3940; Kamri et al., 2018). Thus, Sharia hotels' implementation is inseparable from Sharia's goal as a whole (Maqasid Shariah) (Kamri et al., 2018).

\section{Categorization of Sharia Hotel Attributes} based on Maslahah Levels seen from the Maqasid Shariah Perspective

In the present study, Sharia hotel attributes based on Maslahah levels seen from the Maqasid Shariah perspective are grouped. 
In this study, Dharuriyat is Muslim tourists' primary need that hotel managers must provide. The attributes of Hajiyat are secondary needs but are also needed to support the success of Dharuriyat matters. Meanwhile, the Tahsiniyat is a complementary one and could become the added-value if the hotel can provide. The categorization is considered necessary because the Muslim tourists' compliance level to the Sharia law differs. Those labeled as strict-practicing Muslims would crave their religious needs to be perfectly met during their journey. On the other hand, loose-practicing Muslims will just count the need-to-have components enough as long as the basic requirements are sufficient, such as Halal food and worship facilities (Mastercard \& CrescentRating, 2019). The categorization of each Sharia hotel attribute based on Maslahah levels can be seen in Table 1 below:

Table 1. Categorization of Attributes based on Maslahah Levels

\begin{tabular}{|c|c|c|}
\hline $\begin{array}{l}\text { Maslahah } \\
\text { Levels }\end{array}$ & Attributes & Source \\
\hline \multirow[t]{5}{*}{$\begin{array}{l}\text { Dharuriyat } \\
\text { (Primary) }\end{array}$} & $\begin{array}{l}\text { 1. Restriction for alcoholic beverages in the hotel } \\
\text { area }\end{array}$ & $\begin{array}{l}\text { (Alam et al., 2019; Battour, } \\
\text { 2018; El-Gohary, 2016; } \\
\text { Henderson, 2010; Kamri et al., } \\
\text { 2018; Rosenberg \& Choufany, } \\
\text { 2009) }\end{array}$ \\
\hline & 2. Availability of certified Halal food & $\begin{array}{l}\text { (Alam et al., 2019; Battour, } \\
\text { 2018; El-Gohary, } 2016 \text {; } \\
\text { Henderson, 2010; Kamri et al., } \\
\text { 2018; Rosenberg \& Choufany, } \\
\text { 2009) }\end{array}$ \\
\hline & 3. Separate praying rooms for men and women & (El-Gohary, 2016) \\
\hline & 4. Ablution facilities inside the hotel room & (Alam et al., 2019) \\
\hline & 5. Separate fitness facilities for men and women & $\begin{array}{l}\text { (Battour, 2018; Kamri et al., } \\
\text { 2018; Rosenberg \& Choufany, } \\
\text { 2009) }\end{array}$ \\
\hline \multirow[t]{5}{*}{$\begin{array}{l}\text { Hajiyat } \\
\text { (Secondary) }\end{array}$} & 1. Availability of Quran in the hotel room & $\begin{array}{l}\text { (Battour, 2018; El-Gohary, } \\
2016 ; \quad \text { Henderson, 2010; } \\
\text { Rosenberg \& Choufany, 2009) }\end{array}$ \\
\hline & $\begin{array}{l}\text { 2. The availability of praying equipment in the } \\
\text { hotel room }\end{array}$ & $\begin{array}{l}\text { (Alam et al., 2019; Kamri et al., } \\
\text { 2018) }\end{array}$ \\
\hline & 3. Sign of Qibla & $\begin{array}{l}\text { (Battour, 2018; El-Gohary, } \\
\text { 2016; Henderson, 2010; Kamri } \\
\text { et al., 2018; Rosenberg \& } \\
\text { Choufany, 2009) }\end{array}$ \\
\hline & 4. Islamic dress protocol for hotel staff and guests & $\begin{array}{l}\text { (El-Gohary, 2016; Henderson, } \\
\text { 2010; Kamri et al., 2018) }\end{array}$ \\
\hline & 5. Bidet in the bathroom & (Henderson, 2010) \\
\hline
\end{tabular}




\begin{tabular}{|c|c|c|}
\hline Maslahah & Attributes & Source \\
\hline & $\begin{array}{l}\text { 6. The bed and toilet that are against the Qibla's } \\
\text { rules }\end{array}$ & $\begin{array}{l}\text { (El-Gohary, 2016; Henderson, } \\
\text { 2010; Kamri et al., 2018) }\end{array}$ \\
\hline & 7. A family-friendly television canal & $\begin{array}{l}\text { (Alam et al., 2019; Battour, } \\
\text { 2018; El-Gohary, 2016; } \\
\text { Henderson, 2010; Rosenberg \& } \\
\text { Choufany, 2009) }\end{array}$ \\
\hline & 8. Internet filters & (Alam et al., 2019) \\
\hline & 9. Zero night clubs & $\begin{array}{l}\text { (El-Gohary, 2016; Henderson, } \\
\text { 2010) }\end{array}$ \\
\hline & $\begin{array}{l}\text { 10. Artwork that does not expose the shape of the } \\
\text { human body }\end{array}$ & $\begin{array}{l}\text { (El-Gohary, 2016; Rosenberg } \\
\text { \& Choufany, 2009) }\end{array}$ \\
\hline \multirow[t]{4}{*}{$\begin{array}{l}\text { Tahsiniyat } \\
\text { (Tertiary) }\end{array}$} & 1. Special services and facilities during Ramadan & $\begin{array}{l}\text { (Alam et al., 2019; Battour, } \\
\text { 2018) }\end{array}$ \\
\hline & 2. Specific lobby floor for women/families & $\begin{array}{l}\text { (Battour, 2018; El-Gohary, } \\
\text { 2016; Henderson, 2010) }\end{array}$ \\
\hline & 3. Female staff allocation for female guest & $\begin{array}{l}\text { (El-Gohary, 2016; Rosenberg } \\
\& \text { Choufany, 2009) }\end{array}$ \\
\hline & 4. Domination of Muslim workers & (Henderson, 2010) \\
\hline
\end{tabular}

(Source: based on writer's construction, 2020)

Based on Sharia hotels' attributes presented in Table 1, there are five attributes in the Dharuriyat, ten attributes for Hajiyat, and four attributes for Tahsiniyat. The breakdown of those levels is as follows.

\section{Dharuriyat category}

The first attribute in the Dharuriyat category is linked to the prohibition of liquor consumption. Alcoholic drinks in Sharia terminology are called khamr. Referring to the Quran surah Al-Maidah: 90, liquor consumption is forbidden and categorized as the act of Satan (Ministry of Religious Affairs, 2009). Therefore, hotel managers with a Sharia concept cannot serve alcoholic victuals or provide bars like conventional hotels.
Like the prohibition of consuming alcoholic beverages, the command to prioritize Halal food is also a recommendation that must be adhered to as written in the Quran surah Al-Maidah: 88 (Ministry of Religious Affairs, 2009). Hence, Sharia hotels that provide food and beverage are only allowed to circulate Halal products to guests.

Hotels that have a restaurant must guarantee the status of the Halal products they serve according to the Halal certification issued by the authorized Halal authority in the administrative area of a destination (Battour, 2018; Kamri et al., 2018; Razalli et al., 2015). Several Sharia hotels in Indonesia, such as Sofyan, Grand Dafam Rohan, and Unisi, are samples of 
Sharia hotels with Halal-certified restaurants issued by the DSN-MUI.

For the worship area attribute, praying facilities are considered necessary because prayer is the primary responsibility of Muslims as written in the Quran surah Hud: 114 (Ministry of Religious Affairs, 2009). A Muslim is required to commit to praying with certain conditions during their journey.

Separation of worship areas between men and women must be performed in Sharia hotels. By providing two separate rooms or creating a barrier in the same room for each gender, the chance where male and female crowds are mixed can be avoided. A separate place for ablution must also be provided to avoid the potential exposure of awrat (nakedness), which would discomfort other guests.

Even though mosques are possibly available around the hotel area, a Sharia hotel must provide a place for worship. The availability of worship areas is also expected to accommodate Muslim guests visiting the hotel for general purposes other than staying overnight (for example, guests who intend to meet relatives who are staying at the hotel or other guests with specific purposes with the hotel management.) Halal food and worship area availability are two inseparable requirements because both are Muslim tourists' immediate needs in Halal tourism (Mohsin et al., 2016).
Ablution is a legitimate requirement before a Muslim starts practicing prayers. Thus, the availability of facilities for ablution in a hotel room equipped with sufficient access to clean water is one of Sharia hotel's essential attributes. Hotels must provide facilities for ablution to support the perfection of the Muslim guests' praying activities. A clever hotel configuration is essential so that guests can remain clean after the ablution. For illustration, the hotel must install the faucet for ablution away from showering ones, especially faucets for defecating.

The last attribute in the Dharuriyat category is addressing separate fitness facilities for men and women. The separation of areas based on gender in swimming pool facilities aims to prevent adverse incidents. Blending male and female guests in one area allows them to see the opposite gender body parts, potentially leading to sexual desire prohibited by religion.

\section{Hajiyat category}

The first attribute in the Hajiyat category is the availability of Quran and prayer mats in the hotel room. Kamri et al. (2018) stated that the completion of Hajiyat could lead to the perfection of Dharuriyat aspects; thus, hotel managers need to provide support for praying activities in each hotel room. 
The Quran is the holy book for Muslims. Reading the Quran is a must, and this activity will be pleased if the Sharia hotel manager provides the Quran in each hotel room. It is also hoped that the availability of the Quran will affect the minds of Muslim guests who have never read the Quran to start reading it.

Sharia concept hotels also require to present attributes for the Qibla sign to make it easier for guests to understand the direction for performing prayers. That feature would help Muslim guests who are not fully aware of the praying directions in destinations they have just visited.

The attribute of hotel staff and guests' clothing views the guidance that men and women should not show their intimate body parts to others than those are allowed to (mahram). Accordingly, in implementing Sharia hotel management, dress procedures also need to be respected. Hotel staff must follow the Islamic dress code; women are required to wear a headscarf, and the male staff is required to wear clothing that covers their intimate parts. Managers also need to communicate the proper dress code to hotel guests in the hotel area.

The next attribute is the bed and toilet position that should not go in the same direction as the Qibla. This attribute is related to Islamic ethics or practices according to Sharia law. Muslims are prohibited from facing or turning their backs on the Kaaba whenever they defecate or urinate, especially in open spaces. For this reason, Sharia hotel managers are expected to wisely design the position of the toilet so as not to make guests have to violate the intended Islamic values.

Although entertainment facilities are essential in tourism, Sharia hotel managers must be knowledgeable in responding to this subject by not providing entertainment that leads to negativity. Some of the entertainment properties that need to be controlled include television channels, internet access, nightclubs, and other kinds of entertainment. Sharia hotel television channels must prioritize family-friendly programs to prevent guests, especially children, from watching acts that do not follow Sharia principles such as pornography and porno-action.

The ease of access to internet networking makes all ages ranging from children to adults accessing anything through their devices. The hotel should provide an internet filter over the hotel $\mathrm{Wi}$ Fi connection favoring these attributes come to success.

The internet filter also aims to prevent hotel guests from watching shows containing pornography, causing inconvenience, and lessening Sharia concepts' quality. Still associated with 
entertainment, hotels are prohibited from providing entertainment facilities such as nightclubs to prevent Muslim guests from committing adultery and alcoholic drinking.

Also, the artwork's attributes must not represent the shape of the human body. Although the literature study only pronounces the prohibition of displaying the human body, drawing all breathing creatures is prohibited in Sharia law (Bahammam, 2012, p. 263). Installing paintings depicting the shape of the human body or other creatures as decoration should be avoided by Sharia hotels. Hotel managers are expected to be innovative by placing permitted decorations such as pictures of buildings, natural landscapes, or other drawing objects.

\section{Tahsiniyat category}

The first attribute of Tahsiniyat is the availability of specialized services during the month of Ramadan. Ramadan special services aim to support Muslims in many purposes: calling for Suhoor (meals consumed before fasting), opening restaurants that provide food for Iftar (break the fast), as well as preparing an imam to lead Taraweeh (communal prayers) for hotel guests who wish to perform Taraweeh at the hotel's Musalla. Although Muslim travelers have the privilege (ease of restrictions for delaying fasting), it will be an added value for Sharia hotels to provide those types of services.
Still in the same category, the availability of a particular lobby floor for female guests is an essential attribute for Sharia hotels. This attribute is related to the feature concerning staff allocation that adjusts the guest gender to provide convenience for guests who only want to be served by hotel staff of the same gender.

Although this practice requires more complex capacity management, a special lobby floor for female guests can be the contrast value between Sharia hotels and conventional ones. Moreover, this feature can attract Muslim women who want more exclusive Sharia hotel services.

The attribute of Muslim workers' domination remains debatable. Sharia hotel managers can also employ staff with religions other than Islam. Sharia hotels' success does not rest in the religion adhered to by all hotel organizations body, but rather on how staff practices Sharia hotels' attributes since Muslim guests have different needs from other market segments.

The last attribute is the availability of a bidet in the bathroom. In western countries such as America and the European region, a bidet's availability is crucial. Since the bathrooms in conventional western hotels rely on the shower to supply water, Muslim guests might worry about cleaning themselves after defecating following Sharia traditions. Therefore, water access 
based on the facilities is vital for Muslim guests. A bidet is less common in Muslimmajority countries like Indonesia, where people are more accustomed to using a water tap or tabo to clean vital body parts after urinating or defecating.

\section{Conclusion}

The classification of attributes based on Maslahah level helps hotel managers or investors to arrange the priority attributes that must be met to establish or operate a Sharia hotel. In the present study, the

\section{References}

Abdurrahman, Z. (2020). Teori Maqasid AlSyatibi dan Kaitannya dengan Kebutuhan Dasar Manusia Menurut Abraham Maslow. Al-Fikr, 22(1), 52 70. Available online: http://journal.uinalauddin.ac.id/index.php/alfikr/article/ view/15534.

Alam, M. N., Nurzaman, M. S., \& Al Hasan, F. A. (2019). The Influence of Sharia Compliance and Customer Experience on Satisfaction and Loyalty of Muslim Tourist who Visited Sharia Hotel. In 2018 International Conference on Islamic Economics and Business (ICONIES 2018). Advances in Economics, Business and Management Research, 101 (Iconies 2018), 57-63. https://doi.org/10.2991/iconies18.2019.11.

Arfan, A. (2013). Maqasid al-Syariah sebagai Sumber Hukum Islam Analisis terhadap Pemikiran Jasser Auda. AlManahij Jurnal Kajian Hukum Islam, 7(2), 183-194. https://doi.org/10.24090/mnh.v7i2.563

Auda, J. (2008). Maqasid Al-Shariah: An
Dharuriyat attributes should be prioritized, followed by the Hajiyat group. Additionally, the Tahsiniyat group is a complementary attribute.

The attributes of Sharia hotels are not limited to what has been explained in the discussion section. Sharia hotel managers are expected to be innovative in developing new attributes as an added value to advance guest satisfaction as long as they are not contradicting Sharia principles. This research is expected to provide brand new ideas for further researchers to investigate other

Introductory Guide. IIIT Publishers. Available online: https://d1wqtxts 1xzle7.cloudfront.net/ 35227839/maqasid_guide-

Feb_2008.pdf?1413942258=\&respons e-content-

disposition $=$ inline $\% 3 \mathrm{~B}+$ filename $\% 3 \mathrm{D}$ Maqasid_guide_Feb_2008.pdf\&Expir $\mathrm{es}=1608225840 \&$ Signature $=\mathrm{BYbDHq}$ 3mofPMEJZa8YMl8hie5OYomrYh7r 4nrjyYAaTtBpPuJaBDHXXFhctmNI6

Azhani, N. M. A., Zainab, K., \& Hairul, N. I. (2017). Perceived Value and Satisfaction towards ShariahCompliant Hotel. Pertanika Journal of Social Sciences and Humanities, 25(December), 77-87. Available online:

https://www.semanticscholar.org/pape $\mathrm{r} /$ Perceived-Value-and-Satisfactiontowards-Hotel-Azhani-

Zainab/a30b0356647beb8c89a96910d b659602812584ff.

Bahammam, F. S. (2012). Panduan Wisatawan Muslim. Jakarta: Pustaka Al-Kautsar.

Battour, M. (2018). Muslim Travel Behavior in Halal Tourism. In 
Mobilities, Tourism and Travel Behavior - Contexts and Boundaries (pp. 3-16). InTech. https://doi.org/10.5772/intechopen.703 70.

Battour, M., Ismail, M. N., \& Battor, M. (2010). Toward a Halal Tourism Market. Tourism Analysis, 15(4), 461470.

https://doi.org/10.3727/108354210X1 2864727453304.

Betawi, U. (2018). Maqashid Al-Syariah sebagai Dasar Hukum Islam dalam Pandangan Al-Syatibi dan Jasser Auda. Jurnal Hukum Responsif, 6(6), 32-43. Available online: http://jurnal.pancabudi.ac.id/index.php /hukumresponsif/article/view/41.

Busyro. (2019). Maqashid al-Syariah, Pengetahuan Mendasar Memahami Maslahah (1st ed.). Jakarta: Prenada Media Group.

Dewan Syariah Nasional-Majelis Ulama Indonesia (DSN-MUI). (2016). Fatwa Dewan Syariah Nasional-Majelis Ulama Indonesia tentang Pedoman Penyelenggaraan Pariwisata berdasar Prinsip Syariah (108/DSNMUI/X/12/2016). Available online: https://dsnmui.or.id/kategori/fatwa/pag $\mathrm{e} / 3 /$.

Dewan Syariah Nasional-Majelis Ulama Indonesia (DSN-MUI). (2020). Senarai Perusahaan Bersertifikat. Available online: https://dsnmui.or.id/sertifikasi/senaraiperusahaan-bersertifikat/.

El-Gohary, H. (2016). Halal tourism, is it really Halal? Tourism Management Perspectives, 19, 124-130. https://doi.org/10.1016/j.tmp.2015.12. 013.

Henderson, J. C. (2010). Sharia-Compliant Hotels. Tourism and Hospitality Research, 10(3), 246-254. https://doi.org/10.1057/thr.2010.3.

Idris, J., \& Wahab, N. A. (2015). The Competitive Advantages of ShariaCompliant Hotel Concept in Malaysia: SWOT analysis. Proceeding of the 2nd
International Conference on Management and Muamalah 2015 (2nd ICoMM), 2015(2), 978-967. Available online: https://d1wqtxts 1xzle7.cloudfront.net/ 54862187/THE_COMPETITIVE_AD VANTAGES OF SHARIACOM.pdf?1509365754=\&responsecontentdisposition $=$ inline $\% 3 \mathrm{~B}+$ filename $\% 3 \mathrm{D}$ THE COMPETITIVE ADVANTAG ES OF SHARIA COM.pdf\&Expires $=1609144330 \&$ Signature $=$ XeqDfh $2 x i$ nMhc64z6IShB7q1AMx3R4RtX9kEP dn6aiw2Ed82M71WToBmODNm $\sim \mathrm{kV}$ wgAL QG1ql 0Hzik4i23DCdnv268 KdtzVsmOl-fYVtRSw J6S9RcF9iUSiPXmNoTYS2PHmTlEhsf ABSDmpocTBmgt843NBMmCpx03 wndWYxxyri1ZAykxIuiGPZRWUV8 xFyhdrOHigDTjWfi9MH UaMvQO h81TOJ7i7bmwlhVU-QUdd0WOvnrcziawZ-iL- B0xFk0W-

O16X4msszSAFiE $\sim$ K4G01djxviftDV9 XBUoZlCf49-

fNgEe8mgrUeDuniBt39gvyzQJXmqq e2HyaA \&Key-PairId=APKAJLOHF5GGSLRBV4ZA.

Janitra, R. (2017). Hotel Syariah, Konsep, dan Penerapannya. Depok: Raja Grafindo Persada.

Kamri, N., Sarif, S., Ali, N. A., Che Omar, C. M., \& Adaha, N. M. A. (2018). Management of Sharia Compliant Hotel in Malaysia: The Experiences of Waqf Hotels. Proceedings of the 3rd International Halal Conference (INHAC 2016), Inhac 2016, 373-383. https://doi.org/10.1007/978-981-107257-4 34.

Kara, M. (2012). Pemikiran Al-Syatibi tentang Maslahah dan Impelementasinya dalam Pengembangan Ekonomi Syariah. Assets, 2(2), 173-184.

Karim, M. H. A., Ahmad, R., \& Zainol, N. A. (2017). Differences in Hotel Attributes: Islamic hotel and Shariacompliant hotel in Malaysia. Journal of Global Business and Social 
Entrepreneurship (GBSE), 1(2), 157169. Available online: https://www.researchgate.net/profile/ Mohd_Hyrul_Abu_Karim/publication/ 320609686 DIFFERENCES IN_HO TEL_ATTRIBUTES_ISLAMIC_HOT EL AND SHARIA COMPLIANT HOTEL IN MALAY YSIA/links/59f01 52caca272a 2500139 d6/DIFFERENCE S-IN-HOTEL-ATTRIBUTESISLAMIC-HOTEL-AND-SHARIACOMPLIANT-HOTEL-IN-

MALAYSIA.pdf.

Khatib, S. (2018). Konsep Maqashid AlSyari $A h$ : perbandingan antara pemikiran Al-Ghazali dan Al-Syathibi. Jurnal Ilmiah Mizani: Wacana Hukum, Ekonomi, dan Keagamaan, 5(1), 4762.

https://doi.org/10.29300/mzn.v5i1.143 6.

Mansyurah, F. A. (2018). Peluang dan Tantangan Bisnis Hotel Syariah pada Masyarakat Kosmopolitan. AtTaradhi: Jurnal Studi Ekonomi, 9(2), 91. https://doi.org/10.18592/attaradhi.v9i2.2511.

Mastercard, \& CrescentRating. (2019). Global Muslim Travel Index 2019 (Issue April). https://www.crescentrating.com/halalmuslim-travel-market-reports.html.

Ministry of Religious Affairs. (2009). AlQur'an Terjemah dan Tajwid. Sygma Creative Media Corp.

Mohsin, A., Ramli, N., \& Alkhulayfi, B. A. (2016). Halal tourism: emerging opportunities. Tourism Management Perspectives, 19(2016), 137-143. https://doi.org/10.1016/j.tmp.2015.12. 010.

Rachmiatie, A., Fitria, R., Karim, S., \& Ceha, R. (2020). Strategi Komunikasi Pariwisata Halal, Studi Kasus Implementasi Hotel Halal di Indonesia dan Thailand. Amwaluna: Jurnal Ekonomi Dan Keuangan Syariah, 4(1), 55-74.

https://doi.org/https://doi.org/10.29313 /amwaluna.v4i1.5256.

Razalli, M. R., Ismail, R. M., \& Yaacob, N. A. (2015). SIHAT: an assessment tool for Shariah-compliant hotel operations. International Journal of Islamic Marketing and Branding, 1(1), 55. https://doi.org/10.1504/ijimb.2015.068 152.

Rosenberg, P., \& Choufany, H. M. (2009). Spiritual Lodging-the Shariacompliant Hotel Concept. HVS Global Hospitality Services- Dubai, April, 17. Available online: https://www.hvs.com/content/2856.pd f.

Saad, H. E., Ali, B. N., \& Abdel-Ati, A. M. (2014). Sharia-Compliant Hotels in Egypt: concept and challenges. Advances in Hospitality and Tourism Research (AHTR), 2(1), 1-15. Available online: https://dergipark.org.tr/en/pub/ahtr/iss ue/32308/359044.

Salleh, N. Z. M., Hamid, A. B. A., Hashim, N. H., \& Omain, S. Z. (2014). The Practice of Shariah-Compliant Hotel in Malaysia. International Journal of Trade, Economics and Finance, 5(1), 26-30.

https://doi.org/10.7763/ijtef.2014.v5.3 35.

Statistics Indonesia. (2018). Statistik Indonesia 2018. Subdirektorat Publikasi dan Kompilasi Statistik (ed.). Badan Pusat Statistik.

Yusof, T. A. (2020). 42 hotels recognized as Syariah-compliant to attract more Muslim tourists. The New Straits Time. https://www.nst.com.my/news/nation/ 2020/09/621681/42-hotels-recognisedsyariah-compliant-attract-moremuslim-tourists.

Zatadini, N., \& Syamsuri. (2018). Konsep Maqashid Syariah menurut Al-Syatibi dan Kontribusinya dalam Kebijakan Fiskal. Al Falah: Journal of Islamic Economics, 3(2), 111-124. http://dx.doi.org/10.29240/alfalah.v3i2 .587 . 
Zellatifanny, C. M., \& Mudjiyanto, B. (2018). Tipe Penelitian Deskriptif dalam Ilmu Komunikasi. Jurnal Diakom, 1(2), 83-90. Available online:

https://jurnaldiakom.kominfo.go.id/ind ex.php/mediakom/article/view/20 